\title{
日本農薬学会設立趣意書
}

今後予想される人口増や異常気象に対応し, いかにして人類の食糧を確保するか注, 全地球的な重要 課題であり，ここで農薬が果たす役割はきわめて大きいものがあります．また，農薬の食品残留や環境 污染も重大視されており, その現状解析が急がれる一方, 新農薬の評価に当たっては従来の効果や経済 性のほかに安全性の検討が必須となりました。さらに今後は省資源的観点からも対応が必要となりつつ あります。これら農薬に関する諸問題は化学物質の人類および自然環境とのかかわりに関する科学技術 の重要な一分野を形成するものといえましょう。

このように複雑多様化した問題に関係する科学が各方面に分化した形で個々に発展することも大切で ありますが，新しい観点で多方面からの知識を結集してこの分野の科学・技術の 総命化を強力に推進す ることが何よりも肝要であります。

すでに, 関連各学会独自の活動に加えて, 日本農芸化学会が中心となり, 日本忍用動物昆虫学会・日 本植物病理学会・日本雑草学会・植物化学調節研究会・日本学術会議共催の 7 回にわたる農薬科学シンポ ジウム, 農薬工業関係者を中心とした 17 回に及ぶ農薬研究会など, いわゆる学際的な場において相互 交流が図られてまいりました。しかしながら，前述のような事態に対応し農薬学の総合的発展を推進す るためには，新しく恒常的な学会組織を設立することが必要な段階に達したと考えられます。

このような情勢に鑑み, 設立発起人一同は, 内外の関連学会との連絡を密にしつつ, 農薬学の総合的 進歩発展および安全かつ効果的な農薬の開発を図るとともに広く生命科学および環境科学の発展に寄与 することを目的として日本農薬学会を設立し, 生理活性物質の構造と活性, 作用機構, 新農薬のデザイ ン, 合成, 製剂, 分析, さらに農薬の安全性, とくに環境や生体内における代謝・分解・残留や毒性な ぞ, 農薬に関する総合的な研究の促進と情報交換の場を提供することが, 農薬に対する社会的要請に応 えうるものと信じます。また，本学会の設立は，次代を担う優秀な若い研究者および技術者の育成や研 究意欲増進にも大いに貢献するものと思われます.

ここにわれわれは，関係者各位に本学会設立へのご賛同をお願いし，斯界の発展にご貢献下さるよう 切に希望する次第であります。

昭和 50 年 7 月 5 日 


\section{日本農薬学会設立発起人 (五十剖)}

赤塚 尹巳 (茨城大農)

浅川勝（農林省農技研）

明日山秀文 (植物防疫協会)

鮎沢 啓夫 (九大農)

飯田格（千葉大園芸）

石井象二郎 (京大農)

石倉 秀次（海洋センター）

石崎寛 (三重大農)

石塚 皓造（理研）

彌富 喜三（東京農大）

岩田＼cjkstart俊一（農林省農技研）

植木 邦和 (京大農)

上島 俊治（全農）

上杉 康彦（農林省農技研）

上田 喜一（昭和大医）

上田 浩二 (農林水産航空協会)

上田 博夫 (大阪府大農)

内山 正昭 (東京農工大農)

内山 充 (国立衛試)

江藤 守総 (九大農)

遠藤 武雄 (植物防疫協会)

大久保良治（農林省林試）

大島 康義（明治大農）

大政 正隆（林業薬剤協会）

岡本 敏彦（東大薬）

沖本陽一郎（玉川大農）

尾上哲之助（農薬工業会）

柏司(農林省農薬検)

金沢 純（農林省農技研）

川崎 俊郎（農林省林試）

川城踇（国立衛試）

河田党 (植物防疫協会)

川原田 璋 (理研)

桐谷 圭治 (高知農林技研)

熊沢善三郎 (三重大農)

熊野 義夫（城西大薬）

鍬塚 昭三（名大農）

黄耿堂 (理研)

河野 達郎（農林省農技研）

後藤 真康（残留農薬研）

後藤 幹保（学習院大理）

斎藤 哲夫 (名大農)

酒井 清六（大東文化大）

桜井義郎（農林省ウイルス研）
佐藤庄太郎（近畿大農）

佐藤 六郎 (東京農工大農)

獅山 慈孝 (京大農)

柴田 和雄 (理研)

白須 泰彦 (残留農薬研)

進藤 登 (東京農工大農)

杉山浩 (農林省虫試)

鈴木 三郎 (理研)

鈴木 照麿 (農林省農薬検)

鈴木 直治（神戸大農）

諏訪内正名（東京農工大農）

高橋 信孝 (東大農)

武居 三吉

武長 孝 (農業機械化研)

竹松 哲夫 (宇都宮大農)

辰野高（理研）

田中 俊彦 (農林省農技研)

田辺 弘也 (相模女子大)

田村 三郎 (東大農)

田村 浩国（農林省農技研）

塚野豊（農林省農技研）

戸刈義次 (植調研協会)

戸部満壽夫（国立衛試）

長沢 正雄 (農薬工業会)

中島 稔 (京大農)

中村 廣明 (農林省農薬検)

中山 治彦（植調研協会）

野口照久（帝人）

能勢 和夫（農林省農技研）

橋爪 文次（全農）

橋本康（環境庁）

日高醇

平井 篤造（近畿大農）

平野 千里 (高知大農)

深見 順一 (理研)

深海 浩 (京大農)

福田 秀夫（農林省）

福永一夫 (理研)

藤田 稔夫 (京大農)

古坂 澄石 (東北大農研)

細辻 豊二(理研)

堀正㑆（植物防疫協会）

堀口 治夫 (農林省北海道農試)

本田博（東京農大）
前川一之 (九大農)

松井 正直 (東大農)

松中 昭一 (農林省農技研)

松浦 慎治 (農林省食総研)

松原 弘道 (名城大農)

松本 義明 (東大農)

見里 朝正 (理研)

光岡 知足 (理研)

水上 武幸（農林省農技研）

水谷 純也 (北大農)

宮本 純之 (IUPAC)

武藤 聡雄（東京教育大農）

宗像桂 (名大農)

村田 道雄（千葉大園芸）

守谷 茂雄 (農林省九州農試)

安尾俊 (科学技術庁)

山口勇 (理研)

山口 富夫（農林省農技研）

山下 恭平 (東北大農)

山本出 (東京農大)

山本 富夫（農薬工業会）

山本亮

吉沢 長人 (植調研協会)

吉田 孝二 (農林省農薬検)

吉田豊（農薬工業会）

吉村 彰治（農林省）

與良 清 (東大農)

渡辺 博恭 (愛媛大農)

D. G. Crosby（カリフォルニア大）

E. M. Mrak（カリフォルニア大）

E. Y. Spencer（カナダ農務省）

F. Matsumura (ウィスコンシン大)

G. J. N. van der Kerk

(オランダ T.N.O.)

J. Larinkari

$$
\text { (フィンランド化学工業会) }
$$

J. E. Casida（カリフォルニア大）

M. Chiba（カナダ農務省）

P. C. Kearney（アメリカ農務省）

R. D. O'Brien（コーネル大）

T. Narahashi（デューク大）

T. Nakatsugawa（シラキュース大）

T. R. Fukuto（カリフォルニア大） 